\title{
Characterization of FRM-36143 as a new $\gamma$-secretase modulator for the potential treatment of familial Alzheimer's disease
}

Jean-François Blain * D, Matthew G. Bursavich, Emily A. Freeman, Lori A. Hrdlicka, Hilliary E. Hodgdon, Ting Chen, Don E. Costa, Bryce A. Harrison, Sudarshan Kapadnis, Deirdre A. Murphy, Scott Nolan, Zhiming Tu, Cuyue Tang, Duane A. Burnett, Holger Patzke and Gerhard Koenig

\begin{abstract}
Background: Familial Alzheimer's disease (FAD) is caused by mutations in the amyloid precursor protein (APP) or presenilin (PS). Most PS mutations, which account for the majority of FAD cases, lead to an increased ratio of longer to shorter forms of the amyloid beta (Aß) peptide. The therapeutic rationale of $\gamma$-secretase modulators (GSMs) for Alzheimer's disease is based on this genetic evidence as well as on enzyme kinetics measurements showing changes in the processivity of the $\gamma$-secretase complex. This analysis suggests that GSMs could potentially offset some of the effects of PS mutations on APP processing, thereby addressing the root cause of early onset FAD. Unfortunately, the field has generated few, if any, molecules with good central nervous system (CNS) drug-like properties to enable proof-of-mechanism studies.
\end{abstract}

Method: We characterized the novel GSM FRM-36143 using multiple cellular assays to determine its in vitro potency and off-target activity as well as its potential to reverse the effect of PS mutations. We also tested its efficacy in vivo in wild-type mice and rats.

Results: FRM-36143 has much improved CNS drug-like properties compared to published GSMs. It has an in vitro EC 50 for $A \beta_{42}$ of $35 \mathrm{nM}$ in $\mathrm{H} 4$ cells, can reduce $A \beta_{42}$ to $58 \%$ of the baseline in rat cerebrospinal fluid, and also increases the nonamyloidogenic peptides $A \beta_{37}$ and $A \beta_{38}$. It does not inhibit Notch processing, nor does it inhibit 24-dehydrocholesterol reductase (DHCR24) activity. Most interestingly, it can reverse the effects of presenilin mutations on APP processing in vitro.

Conclusions: FRM-36143 possesses all the characteristics of a GSM in terms of A $\beta$ modulation Because FRM-36143 was able to reverse the effect of PS mutations, we suggest that targeting patients with this genetic defect would be the best approach at testing the efficacy of a GSM in the clinic. While the amyloid hypothesis is still being tested with $\beta$-site APPcleaving enzyme inhibitors and monoclonal antibodies in sporadic AD, we believe it is not a hypothesis for FAD. Since GSMs can correct the molecular defect caused by PS mutations, they have the promise to provide benefits to the patients when treated early enough in the course of the disease.

Keywords: Familial Alzheimer's disease, $ү$-Secretase modulator, Presenilin, Mutations, Aggregation, Drug-like properties, $A \beta$, Brain, CSF, Cerebrospinal fluid

\footnotetext{
* Correspondence: jean-francois.blain@mail.mcgill.ca

FORUM Pharmaceuticals Inc, 225 2nd Avenue, Waltham, MA 02451, USA
} 


\section{Background}

Alzheimer's disease (AD) is an age-related and chronic neurodegenerative disease that manifests itself by a progressive cognitive decline followed by gradual personality changes that ultimately result in death, typically 3 to 9 years after diagnosis [1, 2]. Neuropathologically, the disease is characterized by the presence of senile plaques, neurofibrillary tangles, as well as neuronal and synaptic loss in regions involved in learning and memory such as the hippocampus and cortical regions [3]. Senile plaques are composed of beta amyloid (A $\beta$ ) [4-6], which is a proteolytic fragment of the amyloid precursor protein (APP) produced from sequential cleavages by the $\beta$-site APP-cleaving enzyme (BACE) and $\gamma$-secretase (GS). APP is first cleaved by BACE to generate a 99 amino acid fragment (C99) [7], which is then cleaved by GS $[8,9]$ to generate $A \beta$ peptides of different lengths. The most abundant product from these cleavage events is $A \beta_{40}$, but a relatively minor species, $A \beta_{42}$, is deposited predominantly in AD brains [10] and found together in the core of plaques with $\mathrm{A} \beta_{43}$ [11].

$\gamma$-Secretase is a protein complex composed of four different subunits: presenilin (PS), nicastrin (Nct), anterior pharynx-defective 1 (Aph-1), and presenilin enhancer 2 (Pen-2) in a 1:1:1:1 stoichiometry [12], with PS forming the catalytic subunit of GS [8, 9]. It cleaves type I transmembrane proteins and has more than 90 reported substrates [13], of which APP and Notch are the best characterized.

Mutations in the substrate APP [14] and in the GS component PS1/2 [15, 16] have been reported to cause familial $\mathrm{AD}$, with the majority leading to an increase in the ratio of $A \beta_{42}: A \beta_{40}$ [17-19]. It is now well accepted that this increase is not due to an increased production of $A \beta_{42}$ but rather to a reduction in the efficiency of GS to process its substrate (for a review see [20]). The genetic evidence supported the amyloid hypothesis of AD [21-23], which has since been refined to suggest that a form of soluble $A \beta$, rather than the $A \beta$ aggregates found in amyloid plaques, is responsible for neurotoxicity [24].

Because of this accumulation of evidence, the pharmaceutical industry began developing compounds targeting GS to prevent the production of these toxic $A \beta$ peptides, hoping that it could ultimately delay the progression of AD symptoms. Initially, $\gamma$-secretase inhibitors (GSIs) were developed but have since been abandoned as a treatment for AD because of mechanism-based toxicities. This issue has been exemplified in a Phase 3 clinical trial with semagacestat [25] as well as a Phase 2 trial with avagacestat [26]. Weight loss, skin cancers, and infections were among the side effects reported, but most striking was the cognitive decline reported in the semagacestat trial $[25,27,28]$. Inhibition of Notch processing is likely to be the cause of most of these side effects, but the memory decline could also be due to the inhibition of EphA4 processing (involved in dendritic spine formation) [29] or the accumulation of C99 in the membrane [30].

Different classes of molecules termed $\gamma$-secretase modulators (GSMs) were discovered that could shift the processing of $A \beta$ from longer toxic forms to shorter nontoxic forms [31]. Interestingly, these molecules did not prevent the cleavage of Notch and other substrates, thus making them potentially devoid of on-target related side effects. The first generation of GSMs was based on nonsteroidal anti-inflammatory drug (NSAID) derivatives, but further development has since produced molecules with better potency that are more attractive for the treatment of $\mathrm{AD}[20,32]$.

In the present study, we report the characterization of FRM-36143, which came from the optimization of a novel structural class of GSMs. We show that it is an orally active modulator in mice and rats and possesses good pharmacokinetic properties; it reduces longer toxic $A \beta$ species while increasing shorter nontoxic forms. It is devoid of on-target Notch toxicity as well as off-target effects on the cholesterol biosynthetic pathway, specifically 24-dehydrocholesterol reductase (DHCR24), as was reported for the Eisai GSM E2012 [33]. In summary, we believe this compound is an effective new agent for the potential treatment of familial Alzheimer's disease (FAD).

\section{Methods}

\section{Compound}

FRM-36143, (R)-5-(benzofuran-2-yl)-3-(6-methoxy-5-(4methyl-1H-imidazol-1-yl)pyridin-2-yl)-5,6-dihydro-4H-1,2, 4-oxadiazine, was synthesized according to literature procedures (Bursavich MG, Harrison BA, Costa DE, Hodgdon HE, Freeman EA, Hrdlicka LA, Kapadnis S, Moffit J, Murphy DA, Patzke H, Tang C, Wen M, Burnett DA, Koenig G, Blain JF. Design, synthesis and evaluation of a novel series of oxadiazine Gamma Secretase Modulators for familial Alzheimer's disease, Submitted). It was used at $>98 \%$ purity in all assays.

\section{Notch $\Delta \mathrm{E}$ and luciferase reporter constructs}

The wild-type CBF1 binding element was cloned in front of the SV40 promoter-driven luciferase reporter construct of pGL3pro (Promega, Madison, WI, USA) using the following oligonucleotides:

\section{CBF1 Fw $\left(5^{\prime} \rightarrow 3\right.$ '): GATCTGGTGTAAACACGCCGTG GGAAAAAATTTATG \\ CBF1 Rv $\left(5^{\prime} \rightarrow 3^{\prime}\right)$ : GATCCATAAATTTTTTCCCACGG CGTGTTTACACCA}

Oligonucleotides were phosphorylated using T4 polynucleotide kinase and annealed (by heating to $90{ }^{\circ} \mathrm{C}$ and cooling to room temperature in a buffer containing $0.1 \mathrm{M}$ $\mathrm{NaCl}$ ). Plasmid pGL3pro was cleaved with BglII and 
dephosphorylated using alkaline phosphatase. The oligonucleotide pair was then ligated using T4 ligase with the linearized plasmid DNA. A clone containing 6 copies of the CBF1 element in front of the SV40 promoter was chosen. The 6xCBF1-RE/SV40 promoter was excised from pGL3 using XhoI and HindIII, and the fragment transferred to the pGL4.17 [luc2/Neo] vector (Promega) was opened with the same restriction enzymes.

The full length human Notch in plasmid pCMV6-XL5 (Origene, Rockville, MD, USA) was used to amplify a truncated form of Notch (Notch $\Delta \mathrm{E}$ ) containing the 20-aminoacid (a.a.) signal sequence followed by 5 a.a. (PPAQL) in front of the transmembrane domain (a.a. 1735-1747) and intracellular domain (a.a. 1748-2555). The primers used were as follows:

Notch $\triangle \mathrm{E} F \mathrm{Fw}\left(5^{\prime} \rightarrow 3^{\prime}\right)$ :

TTTTGAATTCGCCATGCCGCCGCTCCTGGCGCC CCTGCTCTGCCTGGCGCTGCTGCCCGCGCTCG CCGCACGAGGCCCGCCGGCGCAGCTG CACTTCATGTACGTG

Notch $\Delta$ E Rv $\left(5^{\prime} \rightarrow 3^{\prime}\right):$ TTTTCTAGAAGCTATTACTT GAACGCCTCCGGGATGCGCGC

The resulting DNA fragment was digested with EcoRI and $X b a \mathrm{I}$ and ligated into the pCMV6-XL5 vector (Origene) digested with EcoRI plus XbaI. Plasmid DNA corresponding to pCMV6-XL5 Notch $\triangle \mathrm{E}$ was cut with $\mathrm{Xba \textrm {I }}$, blunted with Klenow polymerase, and the cDNA insert excised with EcoRI. This 2500-bp fragment was then ligated into pSG5 (Stratagene, Agilent, Santa Clara, CA, USA) opened with BamHI/blunt and EcoRI. A point mutation was inserted to obtain Met28Val in order to eliminate a potential start codon. Finally, the cDNA insert of pSG5 Notch $\triangle \mathrm{E} \mathrm{M} 28 \mathrm{~V}$ was transferred to plasmid pCMV6-XL5 by digesting with BglII, filling the protruding ends in with Klenow polymerase, and then digesting with EcoRI. The 2500-bp DNA fragment was then ligated into pCMV6-XL5 DNA that was opened with XbaI, the protruding ends filled in with Klenow, and cut with EcoRI.

\section{Cell-based assays \\ H4 cells}

Human neuroglioma H4 cells stably expressing wild-type human APP751 were used for this assay [34]. Briefly, cells were plated at 15,000 cells/well in 96-well plates and left to settle for $6 \mathrm{~h}\left(37^{\circ} \mathrm{C} ; 5 \% \mathrm{CO}_{2}\right)$. Cells were then washed three times with Pro293 ${ }^{\mathrm{TM}}$ chemically defined medium (Lonza, Walkersville, MD, USA) followed by the addition of the compound ( $0.3 \%$ final DMSO). Plates were incubated overnight, and the supernatant was removed for quantification of $A \beta$ peptides by sandwich enzyme-linked immunosorbent assay (ELISA) (see below). Cytotoxicity was evaluated using Cell-Titer 96 W AQueous One
Solution Cell Proliferation Assay (MTS Assay, Promega) according to the manufacturer's protocol.

\section{Primary cortical neurons}

Primary cultures were established from the neocortex of E17 CD1 mouse embryos (Charles River Laboratories, Wilmington, MA, USA). Following tissue dissection and trituration, the cultures were suspended in Neurobasal $^{\circ}$ medium (Invitrogen, Carlsbad, CA, USA) supplemented with $10 \%$ horse serum (Sigma-Aldrich, St. Louis, MO, USA) and $520 \mu \mathrm{ML}$-glutamine. Cells were plated at 50,000 cells/well in 96-well poly-D-lysine-coated plates. Following incubation at $37{ }^{\circ} \mathrm{C}$ and $5 \% \mathrm{CO}_{2}$ for $4 \mathrm{~h}$, the plating medium was exchanged with $\mathrm{Neurobasal}^{\oplus}$ medium supplemented with $2 \% \mathrm{~B}-27^{\circ}$ (Invitrogen), $520 \mu \mathrm{M}$ of Lglutamine, and $1 \%$ penicillin-streptomycin. An assay was performed eight days after plating (DIV8) by replacing half of the medium with fresh medium containing compound (0.1\% final DMSO concentration). Cultures were incubated overnight for analysis of $A \beta$ peptides by sandwich ELISA and cytotoxicity by MTS assay.

\section{Notch reporter assay}

HeLa cells stably transfected with the 6xCBF1-Luc reporter were transiently transfected with the Notch $\Delta \mathrm{E}$ construct (4 $\mu \mathrm{g}$ DNA $/ 10^{6}$ cells) using Lipofectamine 2000 (Thermo Fisher, Waltham, MA, USA) in 6-well plates. The day after transfection, cells were trypsinized and re-plated in black 96-well clear bottom plates. Cells were left to attach for $4 \mathrm{~h}$ and compounds added for overnight treatment. At the end of treatment, the media was replaced with phosphate-buffered saline (PBS,with $\mathrm{Ca}^{2+} / \mathrm{Mg}^{2+}$ ), Steady-Lite Plus reagent (Perkin Elmer, Hopkinton, MA, USA) was added, and the plate incubated at room temperature for $10 \mathrm{~min}$. Chemiluminescence was then read on an EnVision plate reader (Perkin Elmer).

\section{Desmosterol assay}

HepG2 cells were grown in Eagle's minimal essential medium (EMEM) containing $10 \%$ fetal bovine serum, penicillin $(50 \mathrm{U} / \mathrm{mL})$, and streptomycin $(50 \mathrm{ug} / \mathrm{mL})$ and plated at a density of 1 million cells/well in 6-well plates for the experiment. Four to five days after plating, the cells were washed with Hank's balanced salt solution (HBSS), and compound treatment applied for $2 \mathrm{~h}$ in HBSS. At the end of the treatment, cells were collected, washed with PBS, and pelleted. Sterols were extracted from the cell pellet by adding $100 \mu \mathrm{L}$ PBS and $3 \mathrm{~mL}$ ethylacetate (containing an internal standard of $1 \mathrm{mg} /$ $\mathrm{mL} \mathrm{d}$-cholesterol). Tubes were vortexed for $20 \mathrm{~min}$ and centrifuged at $2000 \times g$ for $20 \mathrm{~min}$ at room temperature. The organic phase was dried under a stream of nitrogen at $40{ }^{\circ} \mathrm{C}$ and the samples reconstituted in $65 \%$ 
methanol. Liquid chromatography-tandem mass spectrometry (LC-MS/MS) analysis was performed using a Shimadzu 20-series UFLC (Shimadzu, Kyoto, Japan) and an API 5500 (Applied Biosystems, Foster City, CA, USA) with a Hypersil GOLD column (100X2.1 mM; Thermo Fisher).

\section{ELISA for $A \beta$ species}

$\mathrm{A} \beta$ peptide levels were quantified by sandwich ELISA using anti-A $\beta_{38}$, anti-A $\beta_{40}$, anti-A $\beta_{42}$, (BioLegend, Dedham, MA, USA) or anti-A $\beta_{37}$ for the capture and 4G8horseradish peroxidase (HRP; BioLegend) for detection. When measuring $A \beta_{37}$ and $A \beta_{38}, 4 G 8-H R P$ was added to the sample for overnight incubation, whereas it was added after the overnight incubation for $1 \mathrm{~h}$ for $\mathrm{A} \beta_{40}$ and $A \beta_{42}$ measurements.

For cell-based assays, freshly collected samples of cultured cell supernatant were added to the plates and incubated at $4{ }^{\circ} \mathrm{C}$ for about $24 \mathrm{~h}$. Detection was performed using SureBlue 3,3,5,5'-tetramethylbenzidine (TMB) peroxidase substrate (KPL, Inc., Gaithersburg, MD, USA) and the plates read on a SpectraMax M5e microplate reader (Molecular Devices, Inc., Sunnyvale, CA, USA). GSMtreated samples were normalized to samples treated with DMSO alone (100 \%) and $5 \mu$ M GSI, DAPT (0 \%; SigmaAldrich). $\mathrm{EC}_{50}$ values were calculated from values reported as percentage of DMSO using nonlinear regression, based on a sigmoidal dose-response (variable slope) model.

For in vivo assessment of compound efficacy, brain tissue and cerebrospinal fluid (CSF) were collected, snap frozen in liquid nitrogen, and stored at $-80{ }^{\circ} \mathrm{C}$. Brain hemispheres were homogenized in $0.6 \%$ diethylamine (DEA) in $50 \mathrm{mM} \mathrm{NaCl}$ containing protease inhibitor cocktail (cOmplete mini, EDTA-free, Roche) using sonication (Branson) at $23 \%$ amplitude for $30 \mathrm{~s}$. Homogenates were spun at $227,000 \times g$ for $25 \mathrm{~min}$ at $4{ }^{\circ} \mathrm{C}$. Supernatants were diluted fivefold in PBS-T (0.05\% Tween-20) containing $0.67 \%$ BSA and added to the ELISA plate. For CSF, samples were diluted threefold in the PBS-T/BSA buffer. Detection was performed using the SuperSignal ${ }^{\mathrm{TM}}$ ELISA Femto substrate (Thermo Fisher), and luminescence was read on an EnVision plate reader (Perkin Elmer).

\section{$A \beta$ aggregation assay}

A $\beta$ peptides (AnaSpec, Fremont, CA, USA) were dissolved at a concentration of $1 \mathrm{mg} / \mathrm{mL}$ in hexafluoroisopropanol (HFIP). Peptides were then mixed at different molar ratios. HFIP was evaporated in a SpeedVac without heating for $15 \mathrm{~min}$. Peptides and mixtures were kept on ice and reconstituted in $50 \mathrm{mM}$ Tris- $\mathrm{HCl}, 1 \mathrm{mM}$ EDTA. Peptides (final concentration: $10 \mu \mathrm{M}$ ) were added to thioflavin $\mathrm{T}$ (final concentration: $2.5 \mu \mathrm{M}$; AnaSpec) in a black 96-well plate. Aggregation was monitored on a SpectraMax M5 plate reader (Molecular Devices, Inc.) at a constant temperature of $25{ }^{\circ} \mathrm{C}$ using excitation/emission of $440 \mathrm{~nm} / 480 \mathrm{~nm}$. Readings were recorded in triplicate every $10 \mathrm{~min}$ for a period of $18 \mathrm{~h}$.

\section{Acute treatment studies in mice and rats}

Mice and rats were maintained on 12/12 h light/dark cycle with food available ad libitum. Drug treatment was prepared in a vehicle of $1 \%$ carboxymethylcellulose (CMC):Tween80 (99.5:0.5). Twelve-week-old wild-type male mice (129S6, Taconic Biosciences, Hudson, NY, USA) or rats (Wistar, Charles River Laboratories) were administered compound p.o. without prior fasting and euthanized by $\mathrm{CO}_{2}$ asphyxiation at specified times postdosing. After extraction of the brain, the olfactory bulb and hindbrain were removed and the cerebral hemispheres separated (mice) or cut in 4 pieces (rats). The cerebellum was removed for bioanalysis of the compound. CSF was collected from the cisterna magna and blood from a cardiac puncture.

\section{Bioanalytical methods}

Cerebellums were homogenized in a Mini-BeadBeater (Biospec Products, Inc., Bartlesville, OK, USA). Brain samples, plasma, and CSF were prepared for LC-MS/MS by precipitating proteins with acetonitrile and vacuum filtration in the presence of an internal standard. Standards were prepared in the corresponding matrix. FRM-36143 was resolved by HPLC (Shimadzu) using a reverse-phase C18 Kinetex column (30X2.1 mM; Phenomenex, Torrance, CA, USA). Following separation, the column effluent was introduced into a triple quadrupole mass spectrometer (API 5500, Applied Biosystems), optimized for detection of FRM-36143 and using multiple reaction monitoring with mass transition of $390.3>215.2$.

\section{Protein binding}

The unbound fraction in brain homogenate $\left(f_{\mathrm{u}, \mathrm{b}}\right)$ was determined in triplicate in the Rapid Equilibrium Dialysis device (8000 Da molecular weight cut-off membrane, Thermo Scientific/Pierce Biotechnology, Rockford, IL, USA). Briefly, FRM-36143 stock solution $(0.1 \mathrm{mg} / \mathrm{mL}$ in acetonitrile) was added to fresh mouse brain homogenate (1:4 dilution with PBS) to achieve a final concentration of $1 \mu \mathrm{g} / \mathrm{mL}$. Aliquots of the brain homogenate $(300 \mu \mathrm{L})$ were loaded into the donor side, and $500 \mu \mathrm{L}$ of PBS into the receiver side of the dialyzer. Upon completion of dialysis that was performed at $37{ }^{\circ} \mathrm{C}$ for $5.5 \mathrm{~h}$ with shaking, aliquots $(100 \mu \mathrm{L})$ of samples taken from both donor and receiver sides were added to an equal volume of PBS or corresponding blank matrix, respectively, followed by three times the volumes of acetonitrile containing internal standard. These samples were then vacuum filtered using a Strata Impact 96-well protein 
precipitation plate (Phenomenex). An aliquot of the filtrate was injected for LC-MS/MS analysis.

\section{Matrix-assisted laser desorption/ionization-time of flight (MALDI-TOF) mass spectrometry}

Immunoprecipitation of carboxyl-terminally truncated $\mathrm{A} \beta$ peptides from $4 \mathrm{~mL}$ of $\mathrm{H} 4$ cell media was conducted using the anti-A $\beta$ antibody $6 \mathrm{E} 10$ (epitope $3-8$ of $\mathrm{A} \beta$; Covance, Inc., Dedham, MA, USA) or 4G8 (epitope 1822 of $A \beta$; Covance, Inc., Dedham, MA, USA) coupled to magnetic beads as described elsewhere [35]. After elution of the immunoprecipitated $A \beta$ peptides, the detection was performed on an UltraFlextreme MALDI-TOF/ TOF instrument (Bruker Daltonics, Bremen, Germany).

\section{Extraction of APP-derived tri-, tetra-, and pentapeptides from living cultured cells}

The extractions were performed according to the methods described by Okochi et al. [36]. Briefly, human embryonic kidney (HEK) cells stably expressing APPsw and PS1 derivatives were cultured to confluence in 10- $\mathrm{cm}$ dishes and the media replaced on the day of the experiment. Cells were treated with FRM-36143 in the presence of prote-

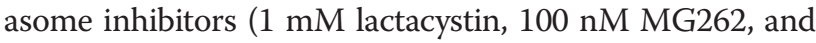
$1 \mathrm{mM}$ epoxomicin) for $1 \mathrm{~h}$. Conditioned media were collected and cells were washed with ice-cold PBS and then immediately boiled for $2 \mathrm{~min}$. A monitoring peptide (IVTL) and protease inhibitors were then added to the boiled samples, which were sonicated for $5 \mathrm{~s}$ three times and centrifuged at $100,000 \times g$ for $1 \mathrm{~h}$. The resultant supernatants were precipitated with TCA on ice for $15 \mathrm{~min}$, centrifuged at $100,000 \times g$ for $1 \mathrm{~h}$, and filtered before being subjected to LC-MS/MS analysis to measure the tri-, tetra-, and pentapeptides as described elsewhere [37].

\section{Modeling and simulation}

A population pharmacokinetic/pharmacodynamic (PK/ PD) analysis was performed to obtain maximal efficacy $\left(E_{\max }\right)$ and concentration leading to $50 \%$ of $E_{\max }\left(\mathrm{EC}_{50}\right)$ using the Phoenix ${ }^{\circ}$ NLME $^{\mathrm{m}}$ (NonLinear Mixed Effect) program (version 6.3, Certara USA, Inc., St. Louis, MO). The goodness of fit was assessed based on visual inspection of curve fitting, Akaike's information criterion (AIC), and precision of parameter estimation.

\section{Results}

FRM-36143 modulates APP processing in vitro and does not affect Notch processing

To first determine the potency of FRM-36143 (structure shown in Fig. 1), H4 cells stably expressing human wildtype (WT) APP751 were treated overnight with the compound, and $A \beta_{42}$ levels were assessed from the conditioned media. Using this assay, it was determined that the $\mathrm{EC}_{50}$ of FRM-36143 for $\mathrm{A} \beta_{42}$ peptide modulation was 35
$\mathrm{nM}$. The potency was then assessed in mouse primary cortical neuron cultures, where the $\mathrm{EC}_{50}$ for $\mathrm{A} \beta_{42}$ was determined to be $53 \mathrm{nM}$ (Fig. 2a), which is within the assay variability and similar to the results from $\mathrm{H} 4$ cells.

To ascertain the GSM nature of FRM-36143, we verified that it did not prevent the processing of Notch. We compared its effect to that of the highly potent GSI, LY411,575. As shown in Fig. 2b, FRM-36143 had no effect on Notch processing $\left(\mathrm{IC}_{50}>10 \mu \mathrm{M}\right)$, as observed by the lack of inhibition in the reporter assay at relevant concentrations. On the other hand, LY-411,575 was extremely potent at blocking Notch cleavage with a measured $\mathrm{IC}_{50}$ of $0.9 \mathrm{nM}$.

In order to assess the effect of FRM-36143 on other $A \beta$ peptides, the APP751 H4 cells were again treated overnight with FRM-36143 and $\mathrm{A} \beta$ levels from the conditioned media assessed by ELISA. We determined the $\mathrm{EC}_{50}$ values to be $35 \mathrm{nM}$ for $\mathrm{A} \beta_{42}, 186 \mathrm{nM}$ for $\mathrm{A} \beta_{40}, 38 \mathrm{nM}$ for $A \beta_{38}$, and $167 \mathrm{nM}$ for $A \beta_{37}$ (Fig. 2c). From the same experiment, conditioned medium from $\mathrm{H} 4$ cells treated with $300 \mathrm{nM}$ of the compound was analyzed by immunoprecipitation followed by mass spectroscopy as described elsewhere [35]. As depicted in Fig. 3, there was a large increase in the levels of $A \beta_{37}$-derived peptides $\left(A \beta_{1-37}\right.$ and $\left.A \beta_{5-37}\right)$ as well as a more modest increase in $A \beta_{1-33}, A \beta_{1-34}$, and $A \beta_{38}$-derived peptides $\left(A \beta_{1-38}\right.$ and $\left.A \beta_{5-38}\right)$. As expected, levels of $A \beta_{1-42}$ were decreased by FRM-36143, and so were the levels of $A \beta_{1-39}$ and $A \beta_{40}$-derived peptides $\left(A \beta_{1-40}\right.$ and $\left.A \beta_{5-40}\right)$. The extent of the change for each peptide is reported in Table 1.

Finally, the levels of $\mathrm{A} \beta$ peptides in conditioned media and of intracellular small peptides produced from $\gamma$ secretase cleavage were measured from HEK cells expressing APPsw following $2 \mathrm{~h}$ of treatment with $1 \mu \mathrm{M}$ of FRM-36143. As shown in Table 2, FRM-36143 significantly increases $A \beta_{38}$ and decreases $A \beta_{40}$ and $A \beta_{42}$ while not changing $A \beta_{\text {total }}\left(A \beta_{38}+A \beta_{40}+A \beta_{42}\right)$. As for the production of small peptides, FRM-36143 increases the production of VVIA and VVIAT, which are the tetraand pentapeptides derived from the fourth cleavage step by GS processing $A \beta_{42}$ to $A \beta_{38}(48 \rightarrow 45 \rightarrow 42 \rightarrow 38)$ and $\mathrm{A} \beta_{43}$ to $\mathrm{A} \beta_{38}(49 \rightarrow 46 \rightarrow 43 \rightarrow 38)$, respectively (Fig. 4).

\section{A $\beta$-lowering effect of FRM-36143 in rodent brain and CSF}

In order to assess the in vivo efficacy of FRM-36143, we opted to use WT animals to avoid any potential confounding factor associated with overexpression of APP. We first treated mice with a single oral dose of $30 \mathrm{mg} / \mathrm{kg}$ and measured the pharmacodynamic markers $A \beta_{37}$ and $A \beta_{42} 6 \mathrm{~h}$ post-treatment. This time point was chosen to eliminate compounds with a half-life too short to induce a pharmacodynamic change in the brain. As shown in Fig. 5, FRM36143 reduced $A \beta_{42}$ by $43 \%$ (Fig. 5a) and increased $A \beta_{37}$ 3.2-fold (Fig. 5b) in mouse brain. We then tested the 
<smiles>COc1nc(C2=NOC[C@H](c3cc4ccccc4o3)N2)ccc1-n1cnc(C)c1</smiles>

compound in rats to compare its effect in brain and CSF. We observed a $30 \% \mathrm{~A} \beta_{42}$ reduction in the brain (Fig. 6a) accompanied with a 2.5-fold increase in $A \beta_{37}$ (Fig. 6b). In CSF, the effect was greater, with a $58 \%$ reduction in $A \beta_{42}$ (Fig. 6c) and a 20-fold increase in $A \beta_{37}$ (Fig. 6d). Finally, in order to determine the in vivo $\mathrm{A} \beta_{42} \mathrm{EC}_{50}$ of FRM36143 , we performed a time course study in mice. We treated the animals with oral doses of 10 and $30 \mathrm{mg} / \mathrm{kg}$ and measured brain levels of $A \beta_{37}, A \beta_{38}, A \beta_{40}$, and $A \beta_{42}$ at multiple time points $(0.5,1,2,3,4,6,10,24 \mathrm{~h})$. While $10 \mathrm{mg} / \mathrm{kg}$ induced an increase in $\mathrm{A} \beta_{37}$ and $\mathrm{A} \beta_{38}$, it did not reduce $A \beta_{40}$ and $A \beta_{42}$ to a great extent (Fig. 7a). On the other hand, the $30 \mathrm{mg} / \mathrm{kg}$ dose led to $40 \%$ and $45 \%$ peak reductions of $A \beta_{40}$ and $A \beta_{42}$, respectively, with a calculated $A U C_{0 \rightarrow 24 h}$ of $31 \%$ for $A \beta_{40}$ and $34 \%$ for $A \beta_{42}$ (Fig. 7b). Peak increases of 3.1-fold and 2-fold were observed for $A \beta_{37}$ and $A \beta_{38}$, respectively. Using the exposure shown in Fig. $7 d$, we performed population PK/PD model fitting for the effect on $\mathrm{A} \beta_{42}$ and calculated the $E_{\max }$ to be 0.51 (CV: $15 \%)$ and the in vivo $\mathrm{EC}_{50}$ to be $78 \mathrm{nM}(2.5-$ $97.5 \% \mathrm{CI} ; 4.6-151 \mathrm{nM}$; unbound plasma concentration). Given the very small effect of the GSM at $10 \mathrm{mg} / \mathrm{kg}$, the

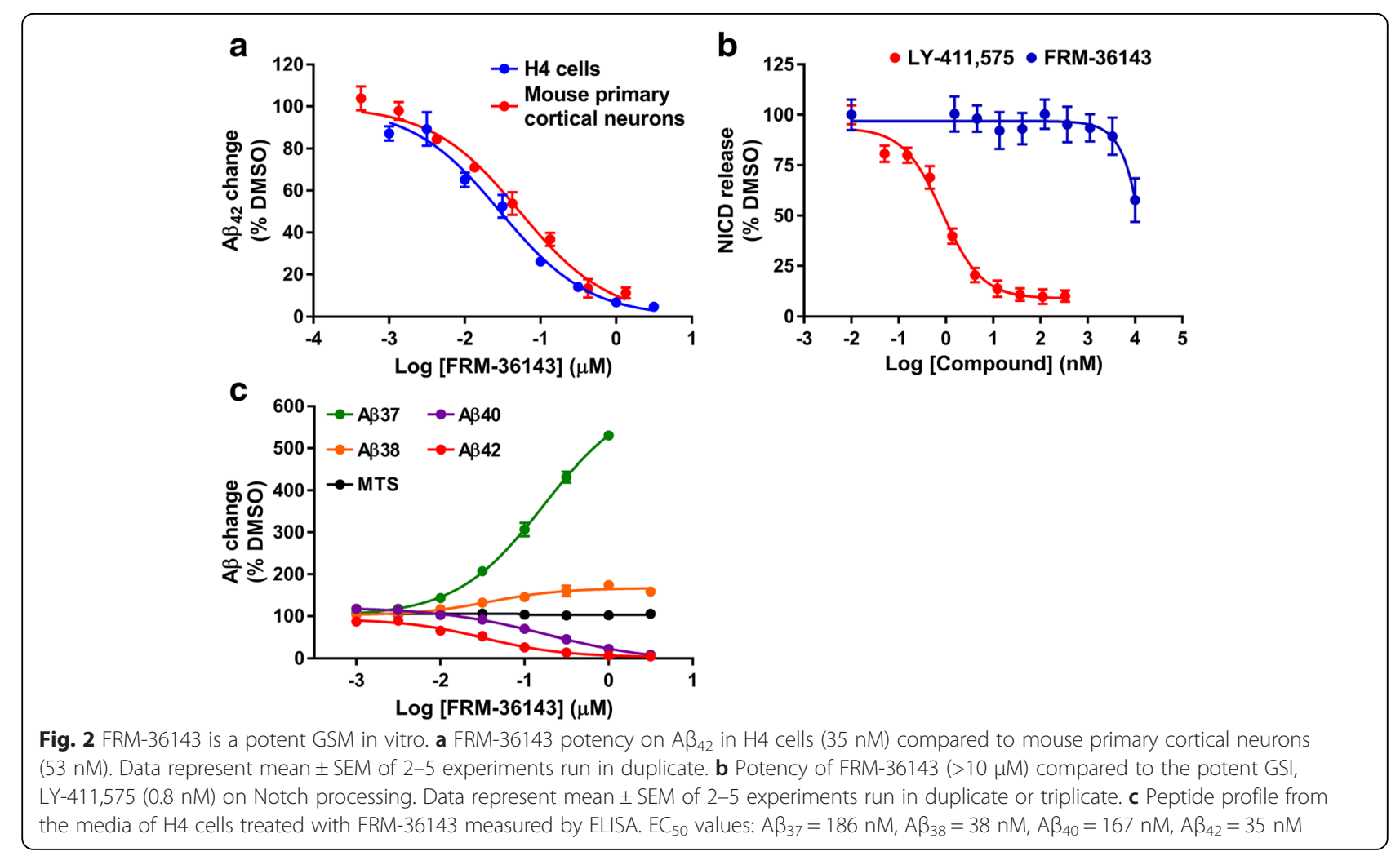



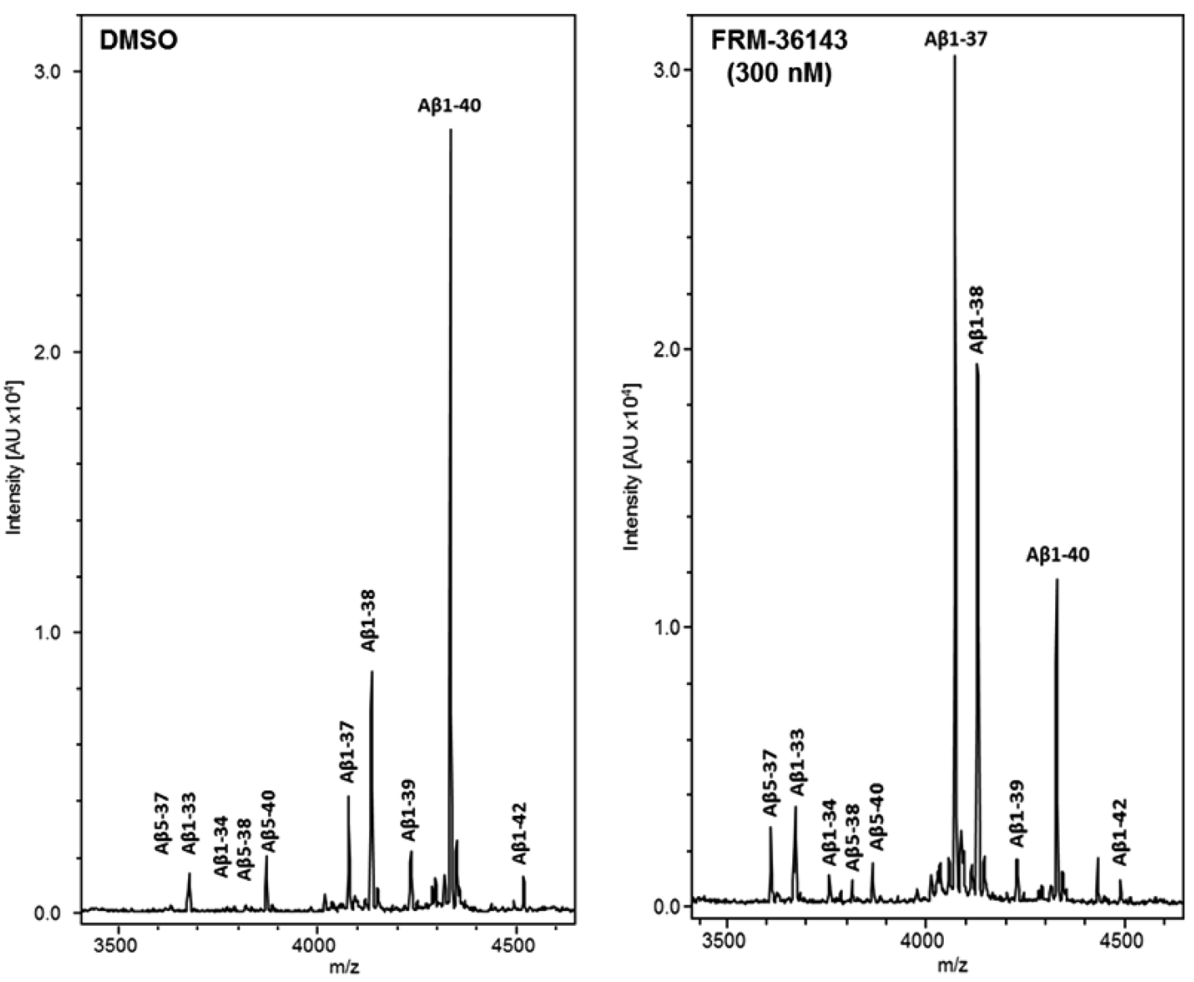

Fig. 3 FRM-36143 affects multiple A $\beta$ isoforms to different extents. Mass spectrometry traces showing the peptide profile in $\mathrm{H} 4$ cell culture media after overnight treatment with DMSO (left) or 300 nM FRM-36143 (right). Measurements are semi-quantitative. Note that peak height is relative for each A isoform, and it should not be compared between peptides since the ionization efficiency and hydrophobicity might be different for each $A \beta$ isoform

model did not capture the data well enough to be included in the parameters estimation; hence, only the $30 \mathrm{mg} / \mathrm{kg}$ data were used (Fig. 7c).

The increases in shorter peptides $A \beta_{37}$ and $A \beta_{38}$ led us to investigate how they affected the aggregation potential of $A \beta_{42}$. As shown in Fig. 8, the short $A \beta$ peptides did not aggregate under our assay conditions, whereas $A \beta_{42}$ showed a $>15$-fold increase in aggregates over time measured as thioflavin $T$ fluorescence. Mixing $A \beta_{37}$ or $A \beta_{38}$ with $A \beta_{42}$ at a ratio of 1:10 (short to long peptide) reduced $A \beta_{42}$ aggregation by more than threefold, and larger ratios of short to long $A \beta$ peptides completely prevented aggregation (data not shown).

\section{FRM-36143 does not affect cholesterol metabolism}

The GSM E2012 was reported to inhibit 24dehydrocholesterol reductase (DHCR24), the enzyme responsible for the last step in cholesterol biosynthesis, catalyzing the reduction of desmosterol to cholesterol [33]. In order to test if FRM-36143 had the same off- target activity, we developed an in vitro assay to monitor the accumulation of desmosterol in cells. Using E2012 as the positive control, we determined that its $\mathrm{IC}_{50}$ for DHCR24 was $63 \mathrm{nM}$ and that it maximally inhibited DHCR24 at $1 \mu \mathrm{M}$ (Fig. 9a). We then compared the effect of FRM-36143 relative to $1 \mu \mathrm{M}$ E2012 and found that it only led to a desmosterol accumulation of $1.1 \%$ at $1 \mu \mathrm{M}$ and $2.6 \%$ at $10 \mu \mathrm{M}$ (Fig. 9b). This result suggests that FRM-36143 does not have off-target activity at DHCR24.

\section{FRM-36143 reverses the effect of FAD PS1 mutations}

We wanted to verify the potential of FRM-36143 to reverse the effect of FAD PS1 mutations towards APP processing. We tested the effect of the compound in cell lines overexpressing APPsw together with different forms of FAD PS1 mutations (H163R, M233L, or R278I). As shown in Fig. 10a, the three PS1 mutants produced less $A \beta$ overall compared to the WT. PS1 mutations are associated with increased $A \beta_{42}: A \beta_{40}$ ratios,

Table 1 Normalized AUC and relative percentage change versus DMSO for each peptide measured by mass spectrometry

\begin{tabular}{|c|c|c|c|c|c|c|c|c|c|c|}
\hline & $A \beta_{5-37}$ & $A \beta_{5-38}$ & $A \beta_{5-40}$ & $A \beta_{1-33}$ & $A \beta_{1-34}$ & $A \beta_{1-37}$ & $A \beta_{1-38}$ & $A \beta_{1-39}$ & $\bar{A} \beta_{1-40}$ & $\overline{A \beta_{1-42}}$ \\
\hline$\overline{\mathrm{DMSO}}$ & 0.4 & 1 & 3 & 1.8 & 0.4 & 5.8 & 11.9 & 3.5 & 38.9 & 1.9 \\
\hline FRM-36143 & 1.9 & 1.5 & 1.2 & 2.9 & 0.5 & 23.6 & 15 & 1.6 & 10 & 0.4 \\
\hline Percentage change (vs. DMSO) & 475 & 150 & 40 & 161 & 125 & 407 & 126 & 46 & 26 & 21 \\
\hline
\end{tabular}


Table 2 A $\beta$ concentration (pM) in the media of HEK cells transfected with $W T$ presenilin. $A \beta_{\text {total }}$ is the result of the addition of $A \beta_{38}, A \beta_{40}$, and $A \beta_{42}$

\begin{tabular}{lccl}
\hline & DMSO & FRM-36143 & $p$ value \\
\hline$A \beta_{\text {total }}$ & $4925 \pm 185$ & $5130 \pm 92$ & 0.161 \\
$A \beta_{38}$ & $750 \pm 62$ & $1548 \pm 39$ & $4.8 \mathrm{E}-05$ \\
$A \beta_{40}$ & $4021 \pm 132$ & $3477 \pm 120$ & $6.2 \mathrm{E}-03$ \\
$\mathrm{~A} \beta_{42}$ & $154 \pm 2$ & $105 \pm 2$ & $6.5 \mathrm{E}-06$ \\
\hline
\end{tabular}

which are also observed here (Fig. 10b), as well as a decrease in the fourth cleavage step of GS as measured by the ratio of $A \beta_{38}: A \beta_{42}$ (Fig. 10c) or the production of the small peptides VVIA $\left(\mathrm{A} \beta_{42} \rightarrow \mathrm{A} \beta_{38}\right)$ and VVIAT $\left(\mathrm{A} \beta_{43} \rightarrow \mathrm{A} \beta_{38}\right)$ (Fig. 10d). In almost all cases, FRM-36143 is able to reverse the effect of the mutations studied. The R278I mutant seems to be more resistant to the effect of the compound. Its $A \beta_{42}: A \beta_{40}$ ratio remains unchanged by the treatment and, while FRM-36143 produced a significant increase on the fourth cleavage step as measured by the $A \beta_{38}: A \beta_{42}$ ratio, it remains much more subtle than for the two other mutants.

\section{Discussion}

The genetic evidence linking APP and PS mutations to AD strongly supports the idea that APP processing and the resulting $A \beta$ peptides are directly linked to the neuropathological changes observed in AD. It has been suggested that $\mathrm{A} \beta$ could mediate toxicity either by driving the disease pathophysiology or by triggering downstream events [38]. A protective mutation in APP has also been reported to delay disease onset and has been linked to decreased production and aggregation of $\mathrm{A} \beta[39,40]$. Targeting the production and/or degradation of $\mathrm{A} \beta$ are thus some of the best rationales to delay the onset of symptoms. $\gamma$-Secretase, with its core catalytic component presenilin, has been a prime target to address the amyloid pathology. Unfortunately, early efforts at developing GSIs were met with clinical failure. These compounds showed no substrate selectivity, which led to undesirable side effects such as skin cancers, weight loss, infections, and even exacerbated memory decline $[25,27,28]$. After the discovery by Weggen et al. [31] that a subset of NSAIDs could selectively lower $A \beta_{42}$ without affecting the initial cleavage step by GS ( $\varepsilon$ cleavage), a lot of research was dedicated to finding new generations of compounds that could mediate similar effects [20,32]. In our quest to discover GSMs that satisfy all known empirical rules of good central nervous system (CNS) drug-like properties [41-43], we synthesized FRM-36143 (Bursavich MG, Harrison BA, Costa DE, Hodgdon HE, Freeman EA, Hrdlicka LA, Kapadnis S, Moffit J, Murphy DA, Patzke H, Tang C, Wen M, Burnett DA, Koenig G, Blain JF. Design, synthesis and evaluation of a novel series of oxadiazine Gamma Secretase Modulators for familial Alzheimer's disease, Submitted). Characterization of this compound proved it to be an excellent modulator of $\gamma$-secretase with potential for treating FAD.

We evaluated the potential of FRM-36143 to reduce $\mathrm{A} \beta_{42}$ levels in cells and found that it did with an $\mathrm{EC}_{50}$ of 35-53 nM. When looking at other peptides, we found the $\mathrm{EC}_{50}$ for $\mathrm{A} \beta_{38}(38 \mathrm{nM})$ to be similar to that of $\mathrm{A} \beta_{42}$, whereas the $E C_{50}$ values for $A \beta_{37}$ and $A \beta_{40}$ were similar to each other (167 and $186 \mathrm{nM}$, respectively) but fivefold less potent when compared to $\mathrm{A} \beta_{42}$. This observation fits well the basic tri/tetra-peptide model put forward by Ihara and colleagues in which $A \beta_{38}$ is mainly derived from $A \beta_{42}$ and $A \beta_{37}$ from $A \beta_{40}[37,44,45]$. This model has since been refined to include multiple routes by which the different $\mathrm{A} \beta$ isoforms could be produced [46]. It has been suggested that GSMs help promote the fourth cleavage cycle of GS as exemplified by the increased ratio of $A \beta_{38}: A \beta_{42}$ [17]. Here we show that FRM-36143 increases that fourth cycle as measured by the intracellular accumulation of the cleavage products VVIA $\left(\mathrm{A} \beta_{42} \rightarrow \mathrm{A} \beta_{38}\right)$ and VVIAT $\left(\mathrm{A} \beta_{43} \rightarrow \mathrm{A} \beta_{38}\right)$ as well as an increase in the $A \beta_{38}: A \beta_{42}$ ratio.

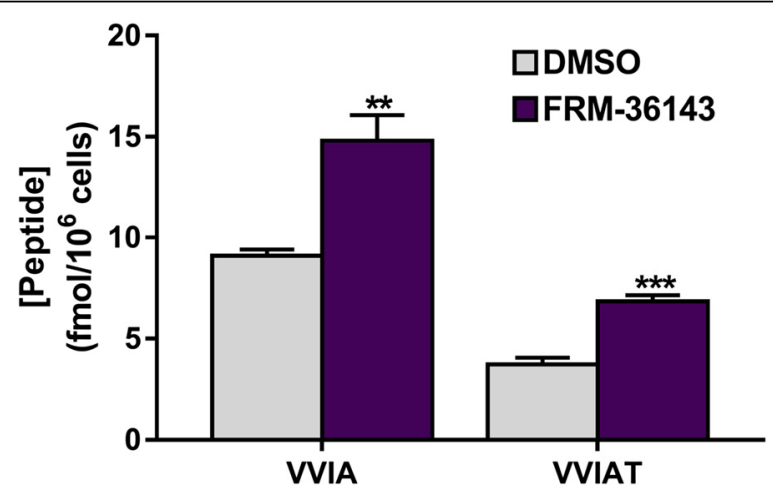

Fig. 4 FRM-36143 increases the fourth cleavage step of gamma secretase. Using the step-wise cleavage model for $A \beta$ cleavage, the generation of the tetrapeptide WIA $\left(A \beta_{42} \rightarrow A \beta_{38}\right)$ and of the pentapeptide WIAT $\left(A \beta_{43} \rightarrow A \beta_{38}\right)$ is increased by FRM-36143 in HEK cells expressing WT presenilin. Data represent mean \pm SEM of $n=4$. Unpaired $t$ test: ${ }^{* *} p<0.01$, ${ }^{* * *} p<0.001$ 

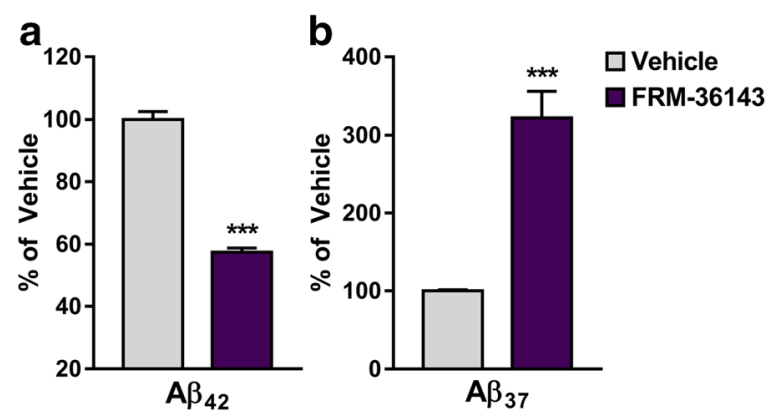

Fig. 5 FRM-36143 is efficacious at modulating $A \beta$ peptides in the mouse brain. Brain $A \beta_{42}(\mathbf{a})$ and $A \beta_{37}(\mathbf{b})$ are reported as percentage change from the vehicle-treated animals. $A \beta_{42}=43 \%$ decrease, $A \beta_{37}=3.2$-fold increase. Data represent mean \pm SEM of 7-12 animals per group. Unpaired $t$ test: ${ }^{* *} p<0.001$

Monitoring of $\mathrm{A} \beta$ peptides by mass spectrometry shows that $A \beta_{39}$ and longer peptides were reduced by FRM-36143, whereas $A \beta_{38}$ and shorter peptides were increased, similarly to what was measurable by ELISA. These changes also hold true for the N-terminally truncated forms $A \beta_{5-\mathrm{x}}$. These findings are important, as it is well accepted that $A \beta_{42}$ is the most aggregation-prone peptide, forming the core of amyloid plaques [10] and, as we show in this study, the shorter forms like $A \beta_{37}$ and $A \beta_{38}$ can prevent its aggregation. Moreover, the reduction in $A \beta_{5-40 / 42}$ is significant, since $N$-terminally truncated $A \beta_{40 / 42}$ were shown to be even more aggregation-prone than $A \beta_{42}$ [47]. Interestingly, it was reported that BACE inhibitors increase the levels of $A \beta_{5-40}$ and $A \beta_{5-42}$ in multiple models [48] as well as in patient CSF [49], suggesting that GSMs might be a preferred treatment strategy if there is concern about N-terminally truncated peptides.

We show that FRM-36143 induced increases of $A \beta_{37}$ with the largest change from baseline of any $A \beta$ peptide (fourfold to fivefold). This result is likely due to the fact that $A \beta_{37}$ is mainly derived from $A \beta_{40}$, which is the most prevalent peptide $(\sim 10$-fold higher than $A \beta_{37}$ and $\left.A \beta_{42}\right)$. Because of this, we believe $A \beta_{37}$ would make an excellent biomarker for the clinic, as its levels are not changed in AD patient CSF [50], and it has the largest dynamic range of all changes observed. On the other hand, $A \beta_{42}$ levels are already reduced in $\mathrm{AD}$ CSF, an observation that could confound the effect of the GSM.

The first cleavage step by GS ( $\varepsilon$ cleavage) is crucial for processing both Notch [51] and APP [9]. Inhibition of
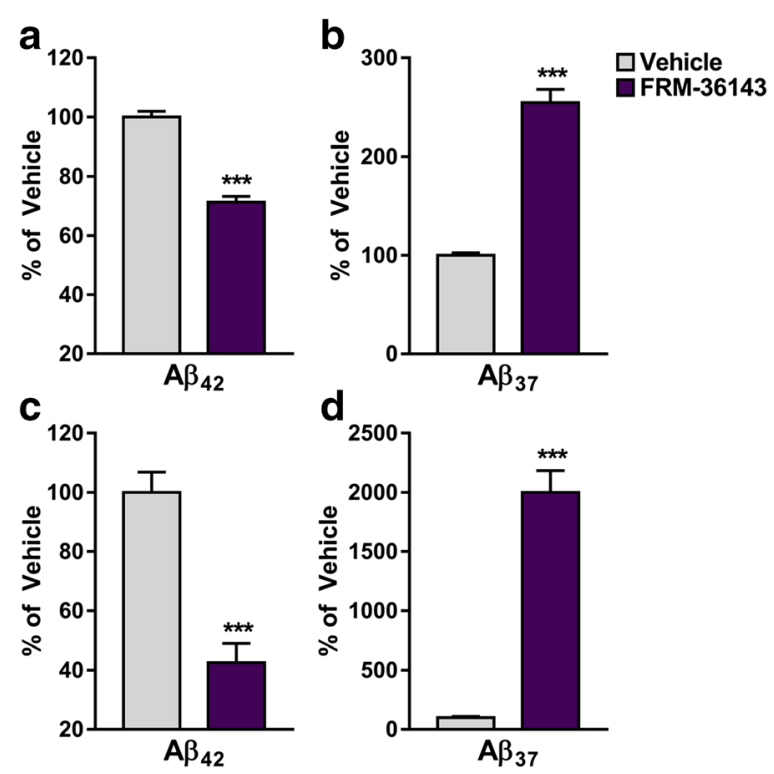

Fig. 6 FRM-36143 is efficacious at modulating A $\beta$ peptides in the rat brain and CSF. Brain (a, b) and CSF (c, d) A $\beta$ peptide changes are reported as percentage change from the vehicle-treated animals. FRM-36143 led to a reduction of $30 \%$ and $58 \%$ reduction of $A \beta_{42}$ in brain (a) and CSF (c), respectively. This was accompanied by increases of 2.5 -fold and 20 -fold of $A \beta_{37}$ in the brain (b) and CSF (d). Data represent mean \pm SEM of 7 animals per group. Unpaired $t$ test: ${ }^{* *} p<0.001$ 

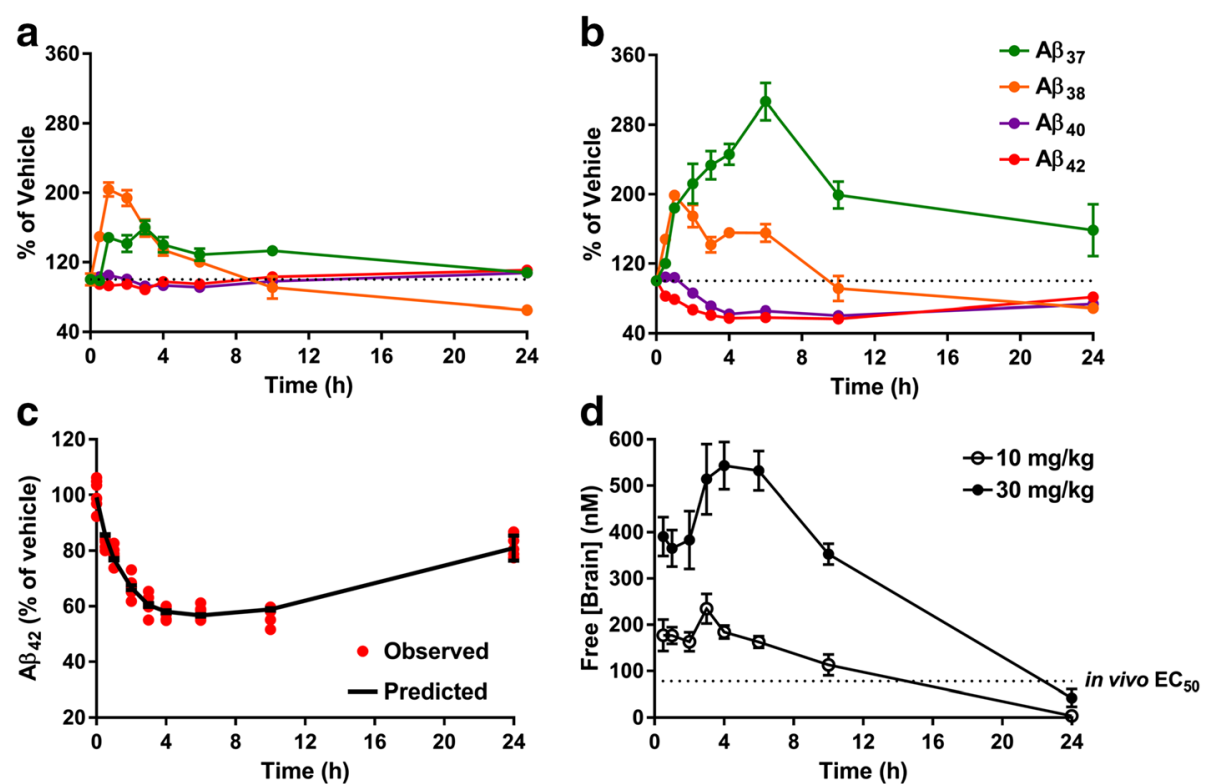

Fig. 7 FRM-36143 induces a sustained change in mouse brain A $\beta$ peptides. Time course of A $\beta$ peptide profile changes in the brain at (a) $10 \mathrm{mg} / \mathrm{kg}$ and (b) $30 \mathrm{mg} / \mathrm{kg}$ FRM-36143. c pharmacokinetic/pharmacodynamic (PK/PD) modeling of the $30 \mathrm{mg} / \mathrm{kg}$ dose. $\mathbf{d}$ Unbound brain exposure of FRM-36143 at 10 and $30 \mathrm{mg} / \mathrm{kg}$. Data represent mean \pm SEM of 5-8 animals per group

Notch processing was one of the main problems reported from GSI clinical trials, where side effects are thought to have resulted in part from Notch-related toxicity $[25,27,28]$. Moreover, GS needs to perform a similar $\varepsilon$ cleavage; otherwise, its substrate C99 accumulates in the membrane and has been reported to be toxic $[52,53]$. The accumulation of C99 has even been suggested as an explanation for the memory decline observed in the semagacestat trial [30]. We thus verified that FRM-36143 did not have the potential to impede the release of the Notch intracellular domain (NICD). We compared its activity to the GSI LY-411,575 in a Notch reporter assay and, as expected, Notch processing was not affected by FRM-36143 $\left(\mathrm{IC}_{50}>10 \mu \mathrm{M}\right)$, while the GSI was extremely potent at blocking the release of NICD $\left(\mathrm{IC}_{50}=0.9 \mathrm{nM}\right)$.
Compounds with the desired effect on $A \beta_{42}$ in vitro were tested in animals to assess their pharmacokinetic (PK) and pharmacodynamic (PD) properties. We first assessed the effect of a $30 \mathrm{mg} / \mathrm{kg}$ oral dose of FRM36143 after $6 \mathrm{~h}$ in mouse brain and found that it produced a $43 \%$ reduction in $A \beta_{42}$ accompanied by a 3.2fold increase in $A \beta_{37}$ at an unbound brain concentration of $427 \mathrm{nM}$. Interestingly, when we dosed at $90 \mathrm{mg} / \mathrm{kg}$ we did not achieve significantly higher exposure or efficacy, suggesting that compound absorption was rate limiting (data not shown). We then wanted to compare the extent of efficacy between brain and CSF, as the latter compartment would be used in the clinic to measure compound efficacy. Dosing rats with $30 \mathrm{mg} / \mathrm{kg}$ FRM36143 led to $30 \%$ and $58 \% \mathrm{~A} \beta_{42}$ reductions in the brain and CSF, respectively, $6 \mathrm{~h}$ post-dose. It also increased

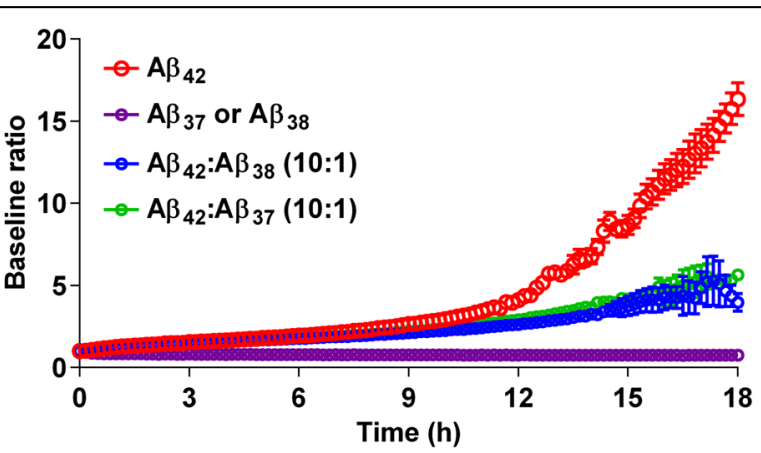

Fig. 8 Short $A \beta$ peptides slow down aggregation of $A \beta_{42}$ in vitro. Co-incubation of the shorter peptides $A \beta_{37}$ or $A \beta_{38}$ with $A \beta_{42}$ in a ratio of 1:10 reduces aggregation of $A \beta_{42}$ by more than threefold after $18 \mathrm{~h}$ under the assay conditions. $A \beta_{37}$ and $A \beta_{38}$ do not aggregate on their own. Data represent mean \pm SEM of two experiments run in triplicate 

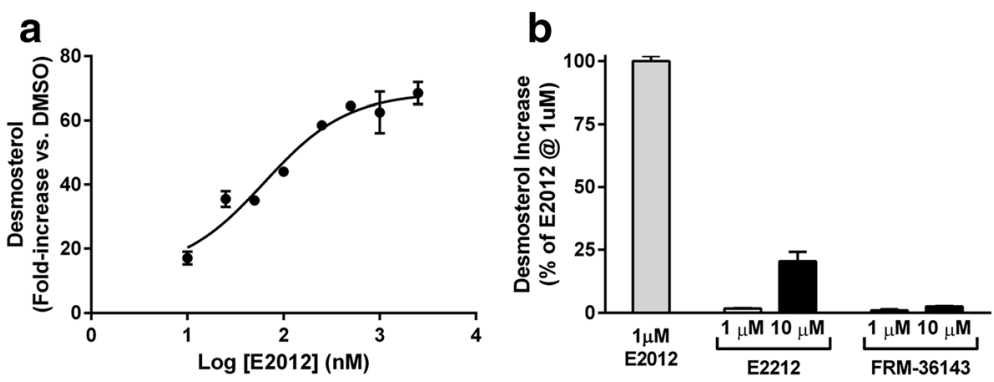

Fig. 9 FRM-36143 does not inhibit DHCR24. Desmosterol change from DMSO was measured in presence of the positive control E2012, the negative control E2212, and FRM-36143. a Dose-response inhibition of DHCR24 by E2012 (IC $50=63$ nM; desmosterol induction at $1 \mu$ M $~ 60-$ fold). b Desmosterol fold increase for the negative control E2212 and FRM-36143 as compared to the response of E2012 at $1 \mu \mathrm{M}$. Data represent mean \pm SEM of one or two experiments run in duplicate

$\mathrm{A} \beta_{37}$ by 2.5 - and 20 -fold in those compartments. Using brain tissue binding, we calculated the unbound brain exposure to be $156 \mathrm{nM}$, whereas it was measured at 122 $\mathrm{nM}$ in the CSF, suggesting a good concordance between the two measures. We found $A \beta$ levels to be low in rats, which put most of the $A \beta_{37}$ values in the vehicle group close to the detection limit of the assay. Because of this limitation, it is possible that increases were overestimated. Despite this issue, it is clear that changes are much larger in CSF compared to brain for both peptides, which is in line with a faster clearance rate of $A \beta$ peptides from the CSF [54].
In order to determine the in vivo $\mathrm{EC}_{50}$ of $\mathrm{FRM}-36143$ and verify the in vitro-in vivo correlation, we performed a time course in mice at two different doses. Modeling brain $\mathrm{A} \beta_{42}$ reduction produced an $\mathrm{EC}_{50}$ of $78 \mathrm{nM}$, which correlates well with the in vitro $\mathrm{EC}_{50}$ of 35 to $53 \mathrm{nM}$ measured in $\mathrm{H} 4$ cells and primary neurons. The model also allowed for an estimation of the maximal brain $\mathrm{A} \beta_{42}$ reduction $\left(E_{\max }\right)$ achievable with FRM-36143, which was calculated to be $51 \%$. Surprisingly, we did not observe any efficacy at the $10 \mathrm{mg} / \mathrm{kg}$ dose on $\mathrm{A} \beta_{42}$ reduction, even though we were reaching exposure levels (unbound brain $\mathrm{Cmax}=235 \mathrm{nM}$ ) well above the $\mathrm{EC}_{50}$
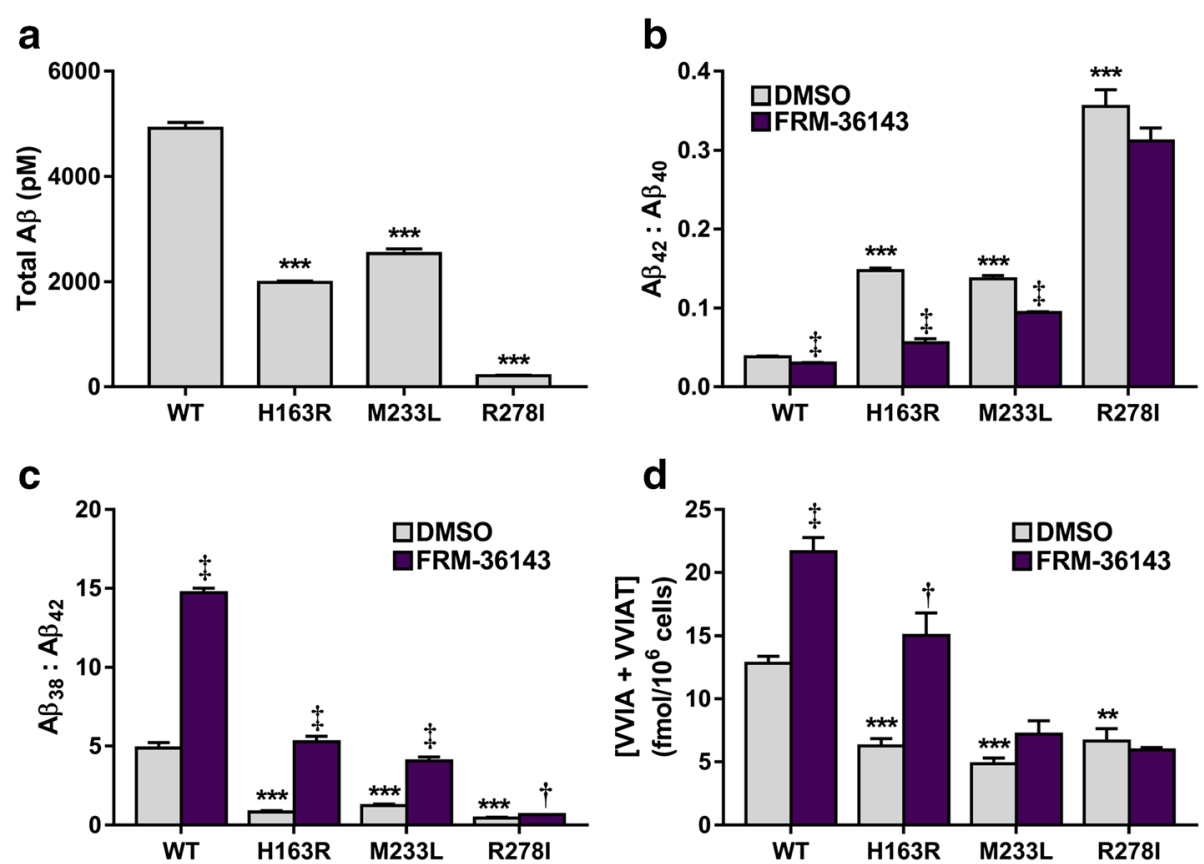

Fig. 10 FRM-36143 reverses the effects of FAD presenilin mutants. a Total A $\beta$ secreted by HEK cells expressing WT or mutant PS. Presenilin mutants cause a partial loss of function of $\gamma$-secretase leading to a decreased secretion of total $A \beta$ peptides. b Presenilin mutations increase the $A \beta_{42}: A \beta_{40}$ ratio, which is reversed by FRM-36143. Presenilin mutations decrease the fourth cleavage cycle of $\gamma$-secretase as measured by the $A \beta_{38}: A \beta_{42}$ ratio (c) or the intracellular production of the peptides WIA and WIAT (d), both of which are reversed by FRM-36143. Data represent mean \pm SEM of $n=4$. Two-tailed unpaired $t$ test: ${ }^{* *} p<0.001$ and ${ }^{* * *} p<0.0001$ : mutants vs. WT, $\neq p<0.0001$ : FRM-36143 vs. DMSO, $\uparrow p<0.01$ : FRM-36143 vs. DMSO 
for more than $6 \mathrm{~h}$. After testing multiple compounds in this class, we empirically observed that in order to achieve significant in vivo efficacy we had to reach unbound concentrations in the brain that approached the $\mathrm{EC}_{90}$ for these compounds. FRM-36143 has an $\mathrm{EC}_{90}$ of $383 \mathrm{nM}$, which is higher than the Cmax achieved at $10 \mathrm{mg} / \mathrm{kg}$.

The potent GSM E2012 was reported to cause lenticular opacity in animals [33]. Because this off-target toxicity takes 12-14 weeks to appear in animals, we developed an assay that allowed us to screen against it in vitro. Eisai identified DHCR24 as being involved in the development of cataracts in animals. They showed that E2012 inhibited the last step in the cholesterol biosynthetic pathway leading to the accumulation of the precursor, desmosterol, in the lens and in plasma as soon as $24 \mathrm{~h}$ after treatment. They had also identified the compound E2212 that did not have this off-target activity [55]. Using this information, we screened for the accumulation of desmosterol in HepG2 cells and found that FRM-36143 was even less potent than the negative control E2212. This result clearly showed that this offtarget activity is avoided by FRM-36143.

Finally, PS mutations have been reported to decrease the efficiency of the fourth cleavage step of APP, leading to a decreased $A \beta_{38}: A \beta_{42}$ ratio [17] as well as an increased $A \beta_{42}: A \beta_{40}$ ratio [56]. GSMs were shown to increase the processivity of the enzyme complex [36], and we confirmed this using FRM-36143. Of the three PS1 mutants we analyzed (H163R, M233L, R278I), all showed a reduction in total $\mathrm{A} \beta$ production compared to WT PS1, highlighting an overall GS partial loss of function [57]. This loss of function was also accompanied by an increased $A \beta_{42}: A \beta_{40}$ ratio and a decreased $A \beta_{38}: A \beta_{42}$ ratio compared to WT PS1. FRM-36143 was able to reverse the effect of the mutations as measured by the ratios as well as increase the production of the fourth cleavage cycle products VVIA $\left(\mathrm{A} \beta_{42} \rightarrow \mathrm{A} \beta_{38}\right)$ and VVIAT $\left(\mathrm{A} \beta_{43} \rightarrow \mathrm{A} \beta_{38}\right)$. The R278I mutant seemed to be resistant to the GSM and, interestingly, it was reported that this mutation impaired endoproteolysis of PS1, which causes a selective increase in $\mathrm{A} \beta_{43}[58,59]$. Moreover, patients carrying this mutation presented with language impairments and did not meet the AD clinical criteria [60].

\section{Conclusions}

In conclusion, we described a novel molecule, FRM-36143, which possesses all the characteristics of a GSM in terms of $A \beta$ modulation, does not inhibit Notch processing, and is devoid of activity against DHCR24. Moreover, the design of FRM-36143 limits its lipophilic nature, enhancing its very good CNS drug-like properties (Bursavich MG, Harrison BA, Costa DE, Hodgdon HE, Freeman EA, Hrdlicka LA, Kapadnis S, Moffit J, Murphy DA, Patzke H,
Tang C, Wen M, Burnett DA, Koenig G, Blain JF. Design, synthesis and evaluation of a novel series of oxadiazine Gamma Secretase Modulators for familial Alzheimer's disease, Submitted) and makes it an excellent candidate for further characterization. Because FAD mutations in PS have been shown to cause a partial loss of function of $\gamma$ secretase $[17,56,57]$, it was rewarding to see that FRM36143 was able to reverse the effect of most PS mutations tested. Given this result, we suggest that targeting a patient population with this genetic defect would be the most straightforward approach to testing the efficacy of a GSM in the clinic.

In sporadic $\mathrm{AD}$, the amyloid hypothesis is not linked to any specific genetic defect; thus, treatment with BACE inhibitors or monoclonal antibodies relies on an ascribed role for $A \beta$ in the disease progression. In contrast, PS mutations underlie the genetic defect in FAD, causing the earlier disease onset. Our data, together with that of others [61], suggest that GSMs can correct the partial loss of function of $\gamma$-secretase caused by many PS mutants. We thus believe that GSMs, like FRM-36143, have the potential to prevent the disease in patients with FAD when treatment starts early in the course of its development.

\begin{abstract}
Abbreviations
AD, Alzheimer's disease; Aph-1, anterior pharynx-defective 1; APP, amyloid precursor protein; APPsw, amyloid precursor protein with a Swedish mutation; AUC, area under the curve; BACE, $\beta$-site APP-cleaving enzyme; $A \beta$, beta amyloid; CNS, central nervous system; CSF, cerebrospinal fluid; DHCR24, 24dihydrocholesterol reductase; $\mathrm{EC}_{50}$, efficacious concentration producing a $50 \%$ effect; $E_{\text {max }}$, maximal effect; $F A D$, familial Alzheimer's disease; $f_{u, b}$, brain unbound fraction; GS, $\gamma$-secretase; GSI, $\gamma$-secretase inhibitor; GSM, $\gamma$-secretase modulator; Nct, nicastrin; NICD, Notch intracellular domain; NSAID, nonsteroidal antiinflammatory drug; PD, pharmacodynamic; Pen-2, presenilin enhancer-2; PK, pharmacokinetic; PS, presenilin; WT, wild type
\end{abstract}

\section{Acknowledgements}

The authors would like to acknowledge Dr. Erik Portelius and Dr. Henrik Zetterberg for help and discussions on the mass spectrometry experiments as well as Dr. Masayasu Okochi for help and discussions on the mutant presenilin experiments.

\section{Funding}

This section is not applicable.

\section{Availability of data and materials}

The raw data behind the results cannot be shared, as they are owned by FORUM Pharmaceuticals.

\section{Authors' contributions}

JFB contributed to the experimental design and the execution and interpretation of all studies and wrote the manuscript. MGB, BAH, and DAB designed FRM-36143, oversaw its synthesis, and contributed to interpretation of the studies. EAF, LAH, HEH, SK, DEC, and DAM contributed to the design, execution, and interpretation of the studies. TC performed the modeling and contributed to its interpretation. SN performed the bioanalytical analyses. ZT contributed to the design of the Notch reporter assay. CT, HP, and GK contributed to the experimental design and interpretation of the studies. $M G B, D A B, H P$, and GK provided comments and final approval on the manuscript. All authors have contributed to drafting different sections of the manuscript and have read and approved the final version.

Authors' information

This section is not applicable. 


\section{Competing interests}

All authors were paid employees of FORUM Pharmaceuticals during the course of this work. There are no non-financial competing interests for any of the authors.

\section{Consent for publication}

This section is not applicable.

\section{Ethical approval and consent to participate}

All procedures were performed with approval from the Institutional Animal Care and Use Committee and were in accordance with the guidelines in the Guide for the Care and Use of Laboratory Animals from the US Department of Health and Human Services.

\section{Received: 5 May 2016 Accepted: 18 July 2016}

\section{Published online: 30 August 2016}

\section{References}

1. $\quad$ Burns A, lliffe S. Alzheimer's disease. BMJ. 2009;338:b158.

2. Querfurth HW, LaFerla FM. Alzheimer's disease. N Engl J Med. 2010;362:329-44.

3. Scheltens P, Blennow K, Breteler MM, de Strooper B, Frisoni GB, Salloway S, Van der Flier WM. Alzheimer's disease. Lancet. 2016;388:505-17.

4. Glenner GG, Wong CW. Alzheimer's disease and Down's syndrome: sharing of a unique cerebrovascular amyloid fibril protein. Biochem Biophys Res Commun. 1984:122:1131-5.

5. Glenner GG, Wong CW. Alzheimer's disease: initial report of the purification and characterization of a novel cerebrovascular amyloid protein. Biochem Biophys Res Commun. 1984;120:885-90.

6. Masters CL, Simms G, Weinman NA, Multhaup G, McDonald BL, Beyreuther K. Amyloid plaque core protein in Alzheimer disease and Down syndrome. Proc Natl Acad Sci U S A. 1985;82:4245-9.

7. Vassar R, Kuhn PH, Haass C, Kennedy ME, Rajendran L, Wong PC, Lichtenthaler SF. Function, therapeutic potential and cell biology of BACE proteases: current status and future prospects. J Neurochem. 2014;130:4-28.

8. De Strooper B, Saftig P, Craessaerts K, Vanderstichele H, Guhde G, Annaert W, Von Figura K, Van Leuven F. Deficiency of presenilin-1 inhibits the normal cleavage of amyloid precursor protein. Nature. 1998;391:387-90.

9. Wolfe MS, Xia W, Ostaszewski BL, Diehl TS, Kimberly WT, Selkoe DJ. Two transmembrane aspartates in presenilin-1 required for presenilin endoproteolysis and gamma-secretase activity. Nature. 1999;398:513-7.

10. Iwatsubo T, Odaka A, Suzuki N, Mizusawa H, Nukina N, Ihara Y. Visualization of A beta $42(43)$ and A beta 40 in senile plaques with end-specific A beta monoclonals: evidence that an initially deposited species is A beta 42(43). Neuron. 1994;13:45-53

11. Welander H, Franberg J, Graff C, Sundstrom E, Winblad B, Tjernberg LO. Abeta43 is more frequent than Abeta40 in amyloid plaque cores from Alzheimer disease brains. J Neurochem. 2009:110:697-706.

12. Sato T, Diehl TS, Narayanan S, Funamoto S, Ihara $Y$, De Strooper B, Steiner H, Haass C, Wolfe MS. Active gamma-secretase complexes contain only one of each component. J Biol Chem. 2007;282:33985-93.

13. Jurisch-Yaksi N, Sannerud R, Annaert W. A fast growing spectrum of biological functions of gamma-secretase in development and disease. Biochim Biophys Acta. 2013;1828:2815-27.

14. Goate A, Chartier-Harlin MC, Mullan M, Brown J, Crawford F, Fidani L, Giuffra $L$, Haynes $A$, Irving $N$, James $L$, et al. Segregation of a missense mutation in the amyloid precursor protein gene with familial Alzheimer's disease. Nature. 1991;349:704-6.

15. Rogaev El, Sherrington R, Rogaeva EA, Levesque G, Ikeda M, Liang Y, Chi H, Lin C, Holman K, Tsuda T, et al. Familial Alzheimer's disease in kindreds with missense mutations in a gene on chromosome 1 related to the Alzheimer's disease type 3 gene. Nature. 1995;376:775-8

16. Sherrington $R$, Rogaev El, Liang $Y$, Rogaeva EA, Levesque $G$, Ikeda M, Chi $H_{\text {, }}$ Lin C, Li G, Holman K, et al. Cloning of a gene bearing missense mutations in early-onset familial Alzheimer's disease. Nature. 1995;375:754-60.

17. Chavez-Gutierrez L, Bammens L, Benilova I, Vandersteen A, Benurwar M, Borgers M, Lismont S, Zhou L, Van Cleynenbreugel S, Esselmann H, et al The mechanism of gamma-Secretase dysfunction in familial Alzheimer disease. EMBO J. 2012;31:2261-74.

18. Szaruga M, Veugelen S, Benurwar M, Lismont S, Sepulveda-Falla D, Lleo A, Ryan NS, Lashley T, Fox NC, Murayama S, et al. Qualitative changes in human gamma-secretase underlie familial Alzheimer's disease. J Exp Med. 2015;212: 2003-13.

19. Li N, Liu K, Qiu Y, Ren Z, Dai R, Deng Y, Qing H. Effect of presenilin mutations on APP cleavage; insights into the pathogenesis of FAD. Front Aging Neurosci. 2016;8:51.

20. Bursavich MG, Harrison BA, Blain JF. Gamma secretase modulators: new Alzheimer's drugs on the horizon? J Med Chem. 2016. doi:10.1021/acs. jmedchem.5b01960.

21. Hardy J, Allsop D. Amyloid deposition as the central event in the aetiology of Alzheimer's disease. Trends Pharmacol Sci. 1991;12:383-8.

22. Hardy JA, Higgins GA. Alzheimer's disease: the amyloid cascade hypothesis. Science. 1992;256:184-5.

23. Selkoe DJ. The molecular pathology of Alzheimer's disease. Neuron. 1991;6: 487-98.

24. Benilova I, Karran E, De Strooper B. The toxic Abeta oligomer and Alzheimer's disease: an emperor in need of clothes. Nat Neurosci. 2012;15:349-57.

25. Doody RS, Raman R, Farlow M, Iwatsubo T, Vellas B, Joffe S, Kieburtz K, He F, Sun $X$, Thomas RG, et al. A phase 3 trial of semagacestat for treatment of Alzheimer's disease. N Engl J Med. 2013;369:341-50.

26. Coric V, van Dyck CH, Salloway S, Andreasen N, Brody M, Richter RW, Soininen $H$, Thein S, Shiovitz T, Pilcher G, et al. Safety and tolerability of the gammasecretase inhibitor avagacestat in a phase 2 study of mild to moderate Alzheimer disease. Arch Neurol. 2012;69:1430-40.

27. Henley DB, Sundell KL, Sethuraman G, Dowsett SA, May PC. Safety profile of semagacestat, a gamma-secretase inhibitor: IDENTITY trial findings. Curr Med Res Opin. 2014;30:2021-32.

28. De Strooper B. Lessons from a failed gamma-secretase Alzheimer trial. Cell. 2014;159:721-6.

29. Inoue E, Deguchi-Tawarada M, Togawa A, Matsui C, Arita K, Katahira-Tayama S, Sato T, Yamauchi E, Oda Y, Takai Y. Synaptic activity prompts gammasecretase-mediated cleavage of EphA4 and dendritic spine formation. J Cell Biol. 2009;185:551-64.

30. Mitani Y, Yarimizu J, Saita K, Uchino H, Akashiba H, Shitaka Y, Ni K, Matsuoka N. Differential effects between gamma-secretase inhibitors and modulators on cognitive function in amyloid precursor protein-transgenic and nontransgenic mice. J Neurosci. 2012;32:2037-50.

31. Weggen S, Eriksen JL, Das P, Sagi SA, Wang R, Pietrzik CU, Findlay KA, Smith TE, Murphy MP, Bulter T, et al. A subset of NSAIDs lower amyloidogenic Abeta42 independently of cyclooxygenase activity. Nature. 2001;414:212-6.

32. Oehlrich D, Rombouts FJ, Berthelot D, Bischoff FP, De Cleyn MA, Jaroskova L, Macdonald G, Mercken M, Surkyn M, Trabanco AA, et al. Design and synthesis of bicyclic heterocycles as potent gamma-secretase modulators. Bioorg Med Chem Lett. 2013;23:4794-800.

33. Nakano-Ito K, Fujikawa Y, Hihara T, Shinjo H, Kotani S, Suganuma A, Aoki T, Tsukidate K. E2012-induced cataract and its predictive biomarkers. Toxicol Sci. 2014;137:249-58

34. Rogers K, Felsenstein KM, Hrdlicka L, Tu Z, Albayya F, Lee W, Hopp S, Miller MJ, Spaulding D, Yang Z, et al. Modulation of gamma-secretase by EVP0015962 reduces amyloid deposition and behavioral deficits in Tg2576 mice. Mol Neurodegener. 2012;7:61

35. Portelius E, Tran AJ, Andreasson U, Persson R, Brinkmalm G, Zetterberg $H_{\text {, }}$ Blennow K, Westman-Brinkmalm A. Characterization of amyloid beta peptides in cerebrospinal fluid by an automated immunoprecipitation procedure followed by mass spectrometry. J Proteome Res. 2007:6:4433-9.

36. Okochi M, Tagami S, Yanagida K, Takami M, Kodama TS, Mori K, Nakayama T, Ihara Y, Takeda M. Gamma-secretase modulators and presenilin 1 mutants act differently on presenilin/gamma-secretase function to cleave Abeta42 and Abeta43. Cell Rep. 2013;3:42-51.

37. Takami M, Nagashima Y, Sano Y, Ishihara S, Morishima-Kawashima M, Funamoto S, Ihara Y. gamma-Secretase: successive tripeptide and tetrapeptide release from the transmembrane domain of beta-carboxyl terminal fragment. J Neurosci. 2009; 29:13042-52.

38. Karran E, Mercken M, De Strooper B. The amyloid cascade hypothesis for Alzheimer's disease: an appraisal for the development of therapeutics. Nat Rev Drug Discov. 2011;10:698-712.

39. Jonsson T, Atwal JK, Steinberg S, Snaedal J, Jonsson PV, Bjornsson S, Stefansson H, Sulem P, Gudbjartsson D, Maloney J, et al. A mutation in APP protects against Alzheimer's disease and age-related cognitive decline. Nature. 2012;488:96-9.

40. Maloney JA, Bainbridge T, Gustafson A, Zhang S, Kyauk R, Steiner P, van der Brug M, Liu Y, Ernst JA, Watts RJ, Atwal JK. Molecular mechanisms of 
Alzheimer disease protection by the A673T allele of amyloid precursor protein. J Biol Chem. 2014;289:30990-1000.

41. Wager TT, Chandrasekaran RY, Hou X, Troutman MD, Verhoest PR, Villalobos A, Will Y. Defining desirable central nervous system drug space through the alignment of molecular properties, in vitro ADME, and safety attributes. ACS Chem Neurosci. 2010;1:420-34

42. Wager TT, Hou X, Verhoest PR, Villalobos A. Moving beyond rules: the development of a central nervous system multiparameter optimization (CNS $\mathrm{MPO}$ ) approach to enable alignment of druglike properties. ACS Chem Neurosci. 2010;1:435-49.

43. Wager TT, Hou X, Verhoest PR, Villalobos A. Central nervous system multiparameter optimization desirability: application in drug discovery. ACS Chem Neurosci. 2016;7:767-75.

44. Funamoto S, Morishima-Kawashima M, Tanimura Y, Hirotani N, Saido TC, Ihara Y. Truncated carboxyl-terminal fragments of beta-amyloid precursor protein are processed to amyloid beta-proteins 40 and 42 . Biochemistry. 2004:43:13532-40.

45. Yagishita S, Morishima-Kawashima M, Ishiura S, Ihara Y. Abeta46 is processed to Abeta40 and Abeta43, but not to Abeta42, in the low density membrane domains. J Biol Chem. 2008;283:733-8.

46. Matsumura N, Takami M, Okochi M, Wada-Kakuda S, Fujiwara H, Tagami S, Funamoto S, Ihara Y, Morishima-Kawashima M. gamma-Secretase associated with lipid rafts: multiple interactive pathways in the stepwise processing of beta-carboxyl-terminal fragment. J Biol Chem. 2014;289:5109-21.

47. Pike CJ, Overman MJ, Cotman CW. Amino-terminal deletions enhance aggregation of beta-amyloid peptides in vitro. J Biol Chem. 1995;270:23895-8.

48. Mattsson N, Rajendran L, Zetterberg H, Gustavsson M, Andreasson U, Olsson M, Brinkmalm G, Lundkvist J, Jacobson LH, Perrot L, et al. BACE1 inhibition induces a specific cerebrospinal fluid beta-amyloid pattern that identifies drug effects in the central nervous system. PLoS One. 2012;7:e31084.

49. Portelius E, Dean RA, Andreasson U, Mattsson N, Westerlund A, Olsson M, Demattos RB, Racke MM, Zetterberg H, May PC, Blennow K. beta-site amyloid precursor protein-cleaving enzyme 1(BACE1) inhibitor treatment induces Abeta5-X peptides through alternative amyloid precursor protein cleavage. Alzheimers Res Ther. 2014;6:75.

50. Portelius $E$, Andreasson U, Ringman JM, Buerger K, Daborg J, Buchhave P, Hansson O, Harmsen A, Gustavsson MK, Hanse E, et al. Distinct cerebrospinal fluid amyloid beta peptide signatures in sporadic and PSEN1 A431E-associated familial Alzheimer's disease. Mol Neurodegener. 2010;5:2.

51. De Strooper B, Annaert W, Cupers P, Saftig P, Craessaerts K, Mumm JS, Schroeter EH, Schrijvers V, Wolfe MS, Ray WJ, et al. A presenilin-1-dependent gamma-secretase-like protease mediates release of Notch intracellular domain. Nature. 1999;398:518-22.

52. Oster-Granite ML, McPhie DL, Greenan J, Neve RL. Age-dependent neuronal and synaptic degeneration in mice transgenic for the $\mathrm{C}$ terminus of the amyloid precursor protein. J Neurosci. 1996;16:6732-41.

53. McPhie DL, Lee RK, Eckman CB, Olstein DH, Durham SP, Yager D, Younkin SG, Wurtman RJ, Neve RL. Neuronal expression of beta-amyloid precursor protein Alzheimer mutations causes intracellular accumulation of a Cterminal fragment containing both the amyloid beta and cytoplasmic domains. J Biol Chem. 1997;272:24743-6.

54. Lu Y, Riddell D, Hajos-Korcsok E, Bales K, Wood KM, Nolan CE, Robshaw AE, Zhang L, Leung L, Becker SL, et al. Cerebrospinal fluid amyloid-beta (Abeta) as an effect biomarker for brain Abeta lowering verified by quantitative preclinical analyses. J Pharmacol Exp Ther. 2012;342:366-75.

55. Yu Y, Logovinsky V, Schuck E, Kaplow J, Chang MK, Miyagawa T, Wong N, Ferry J. Safety, tolerability, pharmacokinetics, and pharmacodynamics of the novel gamma-secretase modulator, E2212, in healthy human subjects. J Clin Pharmacol. 2014:54:528-36.

56. Shimojo M, Sahara N, Mizoroki T, Funamoto S, Morishima-Kawashima M, Kudo T, Takeda M, Ihara Y, Ichinose H, Takashima A. Enzymatic characteristics of I213T mutant presenilin-1/gamma-secretase in cell models and knock-in mouse brains: familial Alzheimer disease-linked mutation impairs gamma-site cleavage of amyloid precursor protein C-terminal fragment beta. J Biol Chem. 2008;283:16488-96.

57. Kretner B, Trambauer J, Fukumori A, Mielke J, Kuhn PH, Kremmer E, Giese A, Lichtenthaler SF, Haass C, Arzberger T, Steiner H. Generation and deposition of Abeta43 by the virtually inactive presenilin- $1 \mathrm{~L} 435 \mathrm{~F}$ mutant contradicts the presenilin loss-of-function hypothesis of Alzheimer's disease. EMBO Mol Med. 2016;8:458-65.
58. Nakaya Y, Yamane T, Shiraishi H, Wang HQ, Matsubara E, Sato T, Dolios G, Wang R, De Strooper B, Shoji M, et al. Random mutagenesis of presenilin-1 identifies novel mutants exclusively generating long amyloid beta-peptides. J Biol Chem. 2005;280:19070-7.

59. Saito T, Suemoto T, Brouwers N, Sleegers K, Funamoto S, Mihira N, Matsuba Y, Yamada K, Nilsson P, Takano J, et al. Potent amyloidogenicity and pathogenicity of Abeta43. Nat Neurosci. 2011;14:1023-32.

60. Godbolt AK, Beck JA, Collinge J, Garrard P, Warren JD, Fox NC, Rossor MN. A presenilin 1 R278I mutation presenting with language impairment. Neurology. 2004;63:1702-4.

61. Kretner B, Fukumori A, Gutsmiedl A, Page RM, Luebbers T, Galley G, Baumann K, Haass C, Steiner H. Attenuated Abeta42 responses to low potency gamma-secretase modulators can be overcome for many pathogenic presenilin mutants by second-generation compounds. J Biol Chem. 2011:286:15240-51.

\section{Submit your next manuscript to BioMed Central and we will help you at every step:}

- We accept pre-submission inquiries

- Our selector tool helps you to find the most relevant journal

- We provide round the clock customer support

- Convenient online submission

- Thorough peer review

- Inclusion in PubMed and all major indexing services

- Maximum visibility for your research

Submit your manuscript at www.biomedcentral.com/submit
) Biomed Central 